\title{
Whitefly Infestation and Economic Comparison of Two Different Pest Control Methods on Soybean Production
}

\author{
DOI: $10.18196 /$ pt.2017.071.110-115
}

\author{
Fitrah Murgianto* and Purnama Hidayat \\ Department of Plant Protection, Faculty of Agriculture, Bogor Agricultural University, \\ Jl. Kamper, IPB Dramaga Campus, Bogor, 16680 Indonesia, Telp. 0251862844 , \\ *Corresponding author, email: fitrah.murgianto@gmail.com
}

\begin{abstract}
Insecticide application is a common practice done by farmers to control the whitefly Bemisia tabaci. While the use of insecticide can suppress the whitefly population, the cost of soybean production is also increased. The objective of this research was to compare the whitefly infestation and economic of two whitefly control methods on soybean production. Two sets of experiments were done, one set with insecticide application and another one without insecticide application. Ten soybean cultivars were used in each set of experiment with completely randomized design and three replications. The whitefly infestation was observed weekly on sample plants on each plot. The benefit and R/C ratio were calculated based on revenue and total costs of soybean production. The average whitefly (egg and nymphs) population on the plots with insecticide application was 4.95 for egg and 5.72 for nymph per leaf, which was lower than those without insecticide application 11.76 for egg and 10.86 for nymph per leaf. The average benefit and R/C ratio for the plots with insecticide application were IDR 9,654,507/ha and 1.51 respectively, while the average benefit and R/C ratio for the plots without insecticide application were IDR 8,706,299/ha and 1.55 respectively. The study can be concluded that growing soybean without insecticide treatment was more efficient than growing soybean with insecticide applications.

Keywords: Bemisia tabaci, Insect pest, Insecticide, Soybean cultivars
\end{abstract}

\begin{abstract}
ABSTRAK
Aplikasi insektisida biasanya dilakukan oleh petani untuk mengendalikan kutu putih Bemisia tabaci. Penggunaan insektisida dapat menekan populasi kutu putih, biaya produksi kedelai juga meningkat. Tujuan dari penelitian ini adalah untuk membandingkan metode pengaendalian hama terhadap kutu putih dan nilai ekonomi pada produksi kedelai. Percobaan dilakukan dengan dua faktor, faktor pertama yaitu aplikasi insektisida dan aplikasi tanpa insektisida. Faktor kedua yaitu sepuluh kultivar kedelai. Percobaan disusun dengan rancangan acak lengkap dan tiga ulangan. Kutu putih diamati setiap minggu pada tanaman sampel pada setiap plot. Keuntungan dan Rasio R/C dihitung berdasarkan pendapatan dan biaya total produksi kedelai. Populasi kutu putih (telur dan nimfa) rata-rata pada plot dengan aplikasi insektisida adalah 4,95 untuk telur dan 5,72 untuk nimfa per daun, yang lebih rendah daripada yang tidak memiliki aplikasi insektisida 1 1,76 untuk telur dan 10,86 untuk nimfa per daun. Rata-rata keuntungan dan rasio R/ C untuk plot dengan aplikasi insektisida masing-masing adalah Rp 9.654.507 / ha dan 1,51, sedangkan rata-rata keutungan dan rasio R / C untuk plot tanpa aplikasi insektisida masing-masing adalah Rp 8.706.299 / ha dan 1,55. Dari penelitian dapat disimpulkan bahwa tumbuh kedelai tanpa perlakuan insektisida lebih efisien dibanding menanam kedelai dengan aplikasi insektisida.

Kata kunci: Bemisia tabaci, Serangga hama, Insektisida, Kultivar kedelai
\end{abstract}

\section{INTRODUCTION}

One of the problem in soybean production is pests and diseases. The whitefly Bemisia tabaci Gennadius, is an important pest that cause significant yield loss of soybean cultivation in Indonesia. Whitefly attack can reduce soybean production up to $80 \%$, moreover in severe attack can cause a crop failure. Whiteflies can lead to damage either directly or indirectly (Hoodle 2013). Direct damage occurs when the stylet from whiteflies pierce the leaves and suck sap that causes chlorosis in plants (Gulluoglu et al. 2010). Nymphs and adult suck the sap from the leaves causing damage to several crops particularly Asteraceae, Compositae, Crucifera, Cucurbitaceae, Euphorbiaceae, Fabaceae, Labiatae, Leguminosae, Malvaceae and Solanaceae (Bayhan et al. 2006). While the indirect damage occurs due to the accumulation of honey dew that attract the sooty mold to growth on the entire surface of the leaf and disrupt the process of photosynthesis (Hilje and Morales 2008). In addition, the whiteflies are also known play role as vectors of viral disease Cowpea mild mottle virus (CPMMV), Blackeye cowpea mosaic virus (BICMV), Bean yellow 
mosaic virus (BYMV), Soybean stunt virus (SSV), Peanut stripe virus (PStV), and Soybean mosaic virus (SMV) on soybean plants (Marwoto and Inayati 2011).

Chemical control is the main option selected by farmers to controlling B. tabaci in the field. Consequently, chemical control has been used extensively in B. tabaci management (Horowitz \& Ishaaya 1996). Selecting more effective insecticides and using them in rotation or combination is necessary. The side effect of insecticide application were killed non-target species, contaminate the environment, and leave a dangerous residue. The control of whiteflies using chemical method has not given a significant result to decrease the population of B. tabaci (Palumbo et al. 2001). According to Norris et al. (2003) this was related to a new strain of whiteflies that easily formed because of intensive pesticides application. The objective of this research was to compare the whitefly infestation and economic of two whitefly control methods on soybean production.

\section{MATERIALS AND METHODS}

Field experiment were conducted at Indonesian BALITKABI research station in Ngale , Ngawi District, East Java. Soybean culitivars used in the experiment were Dena 1, Devon 1, Demas, Detam 3, Grayak 1, Dewah, Gema, Anjasmoro, Dering and Wilis. The field experiment was conducted in the dry season from July to September 2016.

\section{Population Dynamics of Bemisia tabaci}

Each culitivarof soybean was planted on a plot measuring width of $4 \mathrm{~m}$ and length of 20 $\mathrm{m}$, and laid out as completely randomized design with three replications. There were two sets of experiments, one set with insecticide treatments and another set without insecticide treatments.
The insecticide used are Sipermetrin $100 \mathrm{~g} / \mathrm{l}$, Deltametrin $25 \mathrm{~g} / \mathrm{l}$, Klorpirifosfuazuron $50 \mathrm{~g} / \mathrm{l}$, Fipronil $50 \mathrm{~g} / \mathrm{l}$ and Beta Siflutrin $25 \mathrm{~g} / \mathrm{l}$. The total of plots in the two sets of experiments are 60 with the size of each plot is $80 \mathrm{~m}^{2}$. Planting spacing used was $40 \mathrm{~cm}$ between rows and $20 \mathrm{~cm}$ within rows, two plants per hole. In this study, there were no artificial infestations of whiteflies, but whiteflies allowed to attacking naturally. Three percent (Twenty three) plants from each plot and two leaves from each plant (medium and upper parts) were obtained for investigation of whitefly population. Eggs and larvae numbers were determined on the leaves. Observations of whitefly population were conducted every week from 1-10 week after planting (WAP).

\section{Productivity, Benefit and R/C Ratio of Soybean Farm- ing}

For the calculation of the percentage reduction in soybean yields due to the attack whiteflies, then a set of the same study conducted in the same time and same location, but seperate from the experimental plot without insecticide aplication with performed pest control optimally including whiteflies. Pest control on this plot carried out by spraying insecticide once a week from 2-9 week after planting. Observation were carried out on yield soybean production per plot.

Production cost are all cost incurred for the production of soybean farmers during one growing season. Farmers revenue is derived by multiplying production of soybean with the selling price of soybean (Soekartawi 1995). To calculate the revenue can use the formula:

$\mathrm{TR}=\mathrm{Y} \times \mathrm{Py}$

$\mathrm{TR}=$ Total Revenue

$\mathrm{Y}=$ Soybean production in one growing season Py $=$ Selling price of soybean 
The profit is the difference between revenue and production cost. Profit can be calculated using the formula:

$$
\begin{aligned}
& \pi=\mathrm{TR}-\mathrm{TC} \\
& \pi=\text { Profit } \\
& \mathrm{TR}=\text { Total Revenue } \\
& \mathrm{TC}=\text { Total Cost }
\end{aligned}
$$

According to Rahim and Hastuti (2007) analysis of the ratio $\mathrm{R} / \mathrm{C}$ is a comparison between revenue and production costs. The analysis can use the formula:

$$
\begin{aligned}
& \mathrm{R} / \mathrm{C} \text { Ratio }=\mathrm{TR} / \mathrm{TC} \\
& \mathrm{TR} / \mathrm{TC}>1=\text { Profit } \\
& \mathrm{TR} / \mathrm{TC}<1=\text { Loss } \\
& \mathrm{TR} / \mathrm{TC}=1=\text { Equal }
\end{aligned}
$$

\section{Data Analysis}

The data obtained was statistically analyzed using SPSS 17 software.

\section{RESULTS AND DISCUSSIONS}

Population Dynamics of Bemisia tabaci

Table 1. Whitefly Egg Number of Two Treatments on Ten Soybean Culitivars

\begin{tabular}{lccc}
\hline \multirow{2}{*}{ Culitivars } & \multicolumn{2}{c}{ Mean of egg number } & \multirow{2}{*}{ P Value } \\
\cline { 2 - 3 } & Without Insecticide & With Insecticide & \\
\hline Dena & 1.5 & 0.86 & 0.376 \\
Devon & 10.9 & 3.47 & 0.270 \\
Demas & 2.58 & 4.70 & 0.257 \\
Detam & 0.61 & 0.56 & 0.747 \\
Grayak & 5.45 & 3.95 & 0.433 \\
Dewah & 3.46 & 0.79 & 0.187 \\
Gema & 0.47 & 0.31 & 0.493 \\
Anjasmoro & 2.89 & 0.72 & 0.167 \\
Dering & $0.37 \mathrm{~b}$ & $0.64 \mathrm{a}$ & 0.03 \\
Wilis & 0.62 & 0.54 & 0.822 \\
\hline
\end{tabular}

Note: Numbers in the same row are not followed by the same letters are significantly different (Independent T Test, $\mathrm{P}=0.05$ ).

The whitefly population level was relatively low in insecticide treatment than without insecticide treatment (Table 1 and Table 2). On insecti- cide treatments, the population increase still occur even applied insecticide every week (Figure 1 and Figure 2). But the magnitude of the increase in population is not as big as in the experimental plots without insecticide application. The low susceptibility of the whitefly to many insecticides and the reduction of its natural enemy populations, because of applications of non-selective compounds, are factors that have contributed to the increase in the whitefly population in area with insecticide treatment (Byrne and Devonshire 1997).

Table 2. Whitefly Nymph Population of Two Different Treatments on Ten Soybean Culitivars

\begin{tabular}{lccc}
\hline \multirow{2}{*}{ Culitivars } & \multicolumn{2}{c}{ Mean of egg number } & \multirow{2}{*}{ P Value } \\
\cline { 2 - 3 } & Without Insecticide & With Insecticide & \\
\hline Dena & 3.51 & 1.73 & 0.078 \\
Devon & 14.48 & 9.02 & 0.379 \\
Demas & 5.57 & 11.17 & 0.114 \\
Detam & 1.79 & 1.98 & 0.733 \\
Grayak & 11.33 & 12.00 & 0.893 \\
Dewah & 5.90 & 1.74 & 0.122 \\
Gema & 1.52 & 1.31 & 0.739 \\
Anjasmoro & 5.02 & 3.02 & 0.397 \\
Dering & 2.10 & 2.78 & 0.287 \\
Wilis & 2.75 & 2.55 & 0.871 \\
\hline
\end{tabular}

Note: Numbers in the same row are not followed by the same letters are significantly different (Independent T Test, $\mathrm{P}=0.05$ ).

B. tabaci has attacked soybean since 2 WAP (Second trifoliate). The population of B. tabaci continue to increase in the egg phase until 7 WAP (beginning pod development), however the nymph phase until 8 WAP (full pod). The increase occured due to abiotic factor such as temperature. The average temperature during July, August and September were $33.82^{\circ} \mathrm{C}, 31^{\circ} \mathrm{C}$ and $31.77^{\circ} \mathrm{C}$ respectively. According to Butler et al. (1983) B. tabaci needs temperature higher than $26^{\circ} \mathrm{C}$ and $60 \%$ relative humidity for optimum development. Egg population was decreasing at 8 WAP. This was because the soybean plants stop growing and did not form new leaves. 

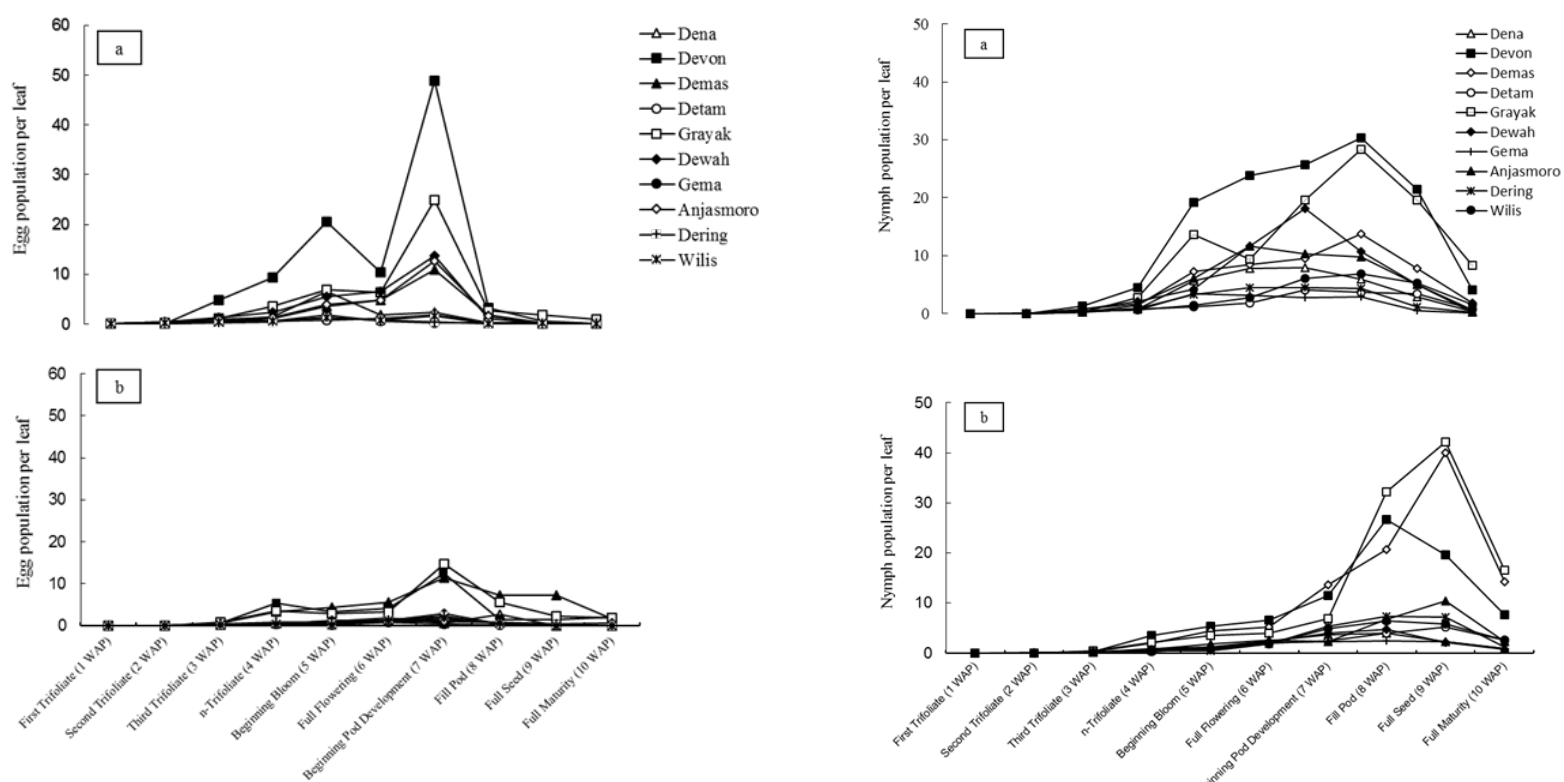

Soybean Growth Stage

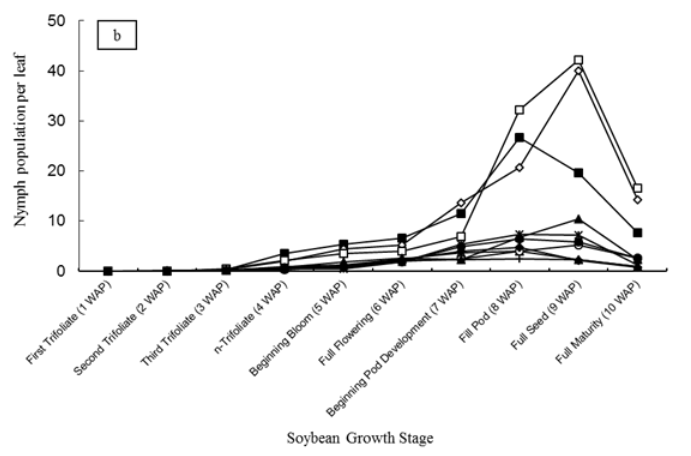

Figure 1. Population Development of B. tabaci Eggs Per Leaf on The Treatment Without Insecticide (a) and With Insecticide (b)

Figure 2. Population Development of $B$. tabaci Nymph Per Leaf On The Treatments Without Insecticide (a) and With Insecticide (b)

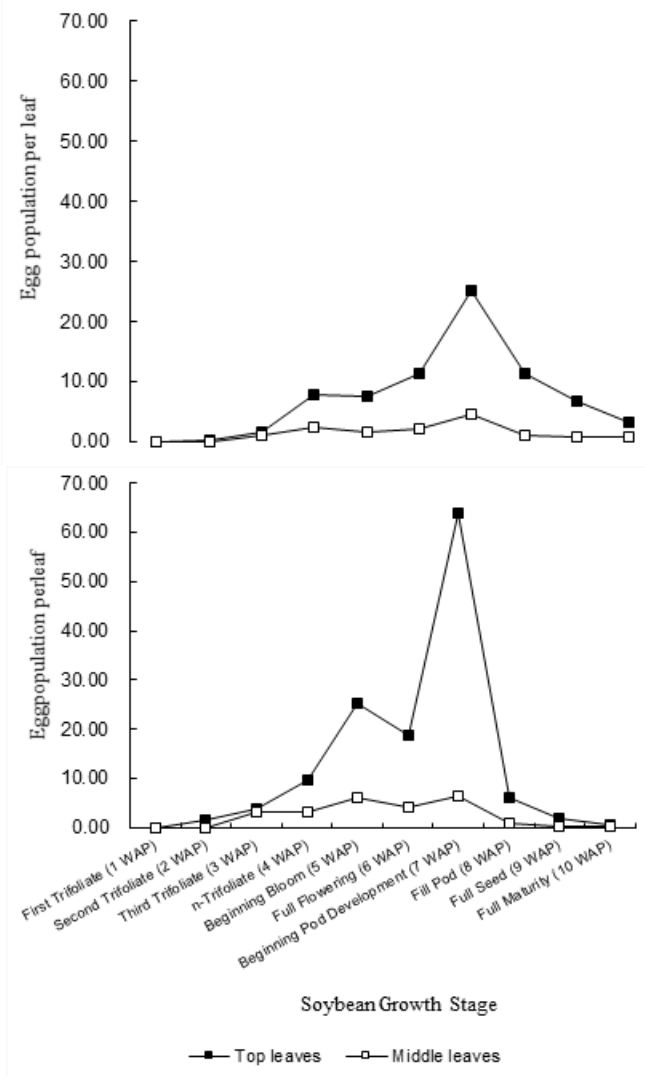

Figure 3. B. tabaci Oviposition Preferences Based On The Position Of Leaves On Insecticide Treatment (a) and Without Insecticide Treatment (b) 
Soybean culitivars with determinate growing type stop growing when the plants are in the full flowering stage. An abiotic factor such as rainfall also affected the populations of B. tabaci. The average rainfall at 8 to $10 \mathrm{WAP}$ (pods maturity) was approximately $15.95 \mathrm{~mm}$. Arif et al. (2006) found that rainfall is negatively correlated with populations of B. tabaci.

The whitefly eggs were the most abundant on the top leaves (Figure 3). According to Gamel (1974) B. tabaci tend to lay eggs on young leaves are caused by nutritional choices to eat and breed.

\section{Soybean Productivity}

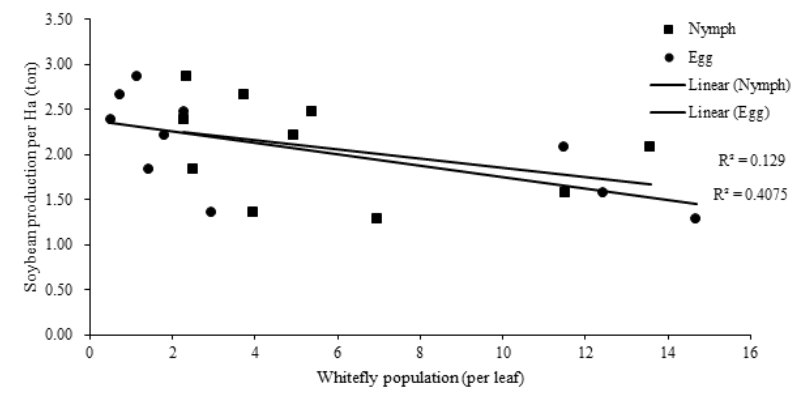

Figure 4. Correlation between B. tabaci population and soybean production in plot with insecticide treatment

The result of this experiment showed that the insecticide aplication did not have significant effect on the productivity of soybean. Bueno et al. (2011) found that the prophylactic use of insecticide in the soybeans does not lead to higher productivity in the field when compared with the technique of Integrated Pest Management (IPM) and biological control. This show that the insecticide application should be used based on the economic threshold. There were correlation between population of the whitefly B. tabaci (eggs and nymphs) and soybean production (Figure 4 and Figure 5).

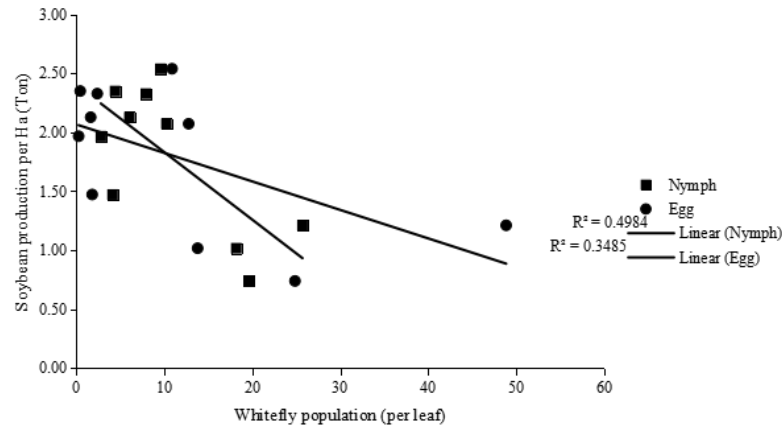

Figure 5. Correlation between $B$. tabaci population and soybean production in plot without insecticide treatment

Highpopulation of B. tabaci definitely caused the lower of soybean productivity. It is caused by the damage of the leaves due to this pest feeding activity. Arifin and Rizal (1989) stated that the decrease in yield components such as number of pods and number of seeds caused by the death of the flowers and young pods due to reduction of photosynthesis capacity caused by leaf damage.

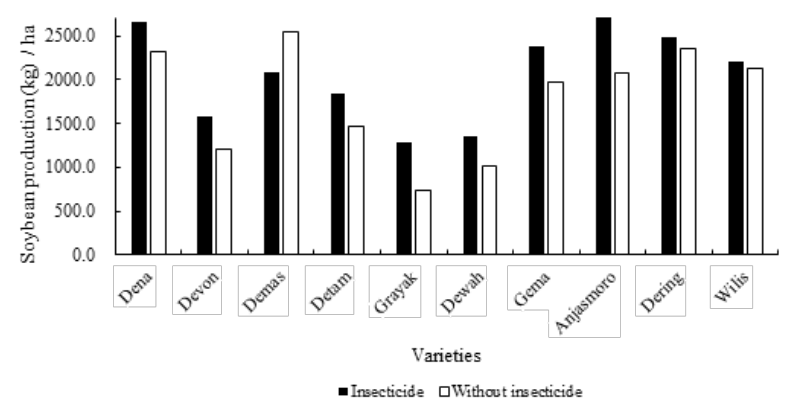

Figure 6. Productivities of 10 soybean culitivars/Ha

In general, soybean growth with insecticide application have greater yield than the soybean without insecticide application (Figure 6), although it did not significantly different. The Demas cultivar had a higher productivity on the plot without insecticides compared to the plot with insecticide treatment. This indicates that the application of insecticides is not always giving a positive influence in the productivity. 
Application of insecticides should be based on the observation of pest population.

\section{Benefit and R/C Ratio of Soybean Farming}

Soybean production costs with insecticide aplication was Rp. 18785333 and without insecticide aplication was Rp. 15760000 per Ha. While soybean production with insecticide aplication was $3977.6 \mathrm{~kg}$ and without insecticide aplication was $3421.6 \mathrm{~kg}$ per Ha. With the selling price of soybean was Rp. 7 150, the revenue were Rp 28439840 and Rp. 24466 299, respectively. The profit were Rp. 9654507 and Rp. 8706299 respectively. The $\mathrm{R} / \mathrm{C}$ ratio was 1.51 for growing soybean with insecticide and 1.55 without insecticide. The ratio of $\mathrm{R} / \mathrm{C}$ means that the cost of $\mathrm{Rp} .1 .00$ will receive a profit of Rp. 1.55 for growing soybean without insecticide. While on the insecticide treatment, the cost of Rp. 1.00 will receive a profit of $\mathrm{Rp}$. 1.51. In other words, in the experiment showed that growing soybean without insecticide treatment was more efficient than growing soybean with insecticide applications. Soekartawi (1995) states that efficient is the comparison of the efforts by the results achieved.

\section{CONCLUSION}

Insecticide application can decrease the population of the whitefly, B. tabaci on the soybean field, but did not always increase the yield significantly. In certain level of the whitefly population, growing soybean without insecticide was more efficient than that with insecticide treatment.

\section{REFERENCES}

Arifin M, A. Rizal. 1989. Ambang ekonomi ulat grayak (Spodoptera litura F.) pada tanaman kedelai varietas orba. Penelitian Pertanian 9 (2): 71-77.
Arif MJ, M.D. Gogi, M. Mirza, K Zia, F Hafeez. 2006. Impact of plant spacing and abiotic factors on population dynamics of sucking insect pests of cotton. Pak. J. Bio. Sci 9 (7): 1364-1369.

Butler GD, T.J. Henneberry, T.E. Clayton. 1983. Bemisia tabaci (Homoptera: Aleyrodidae): development, oviposition, and longetivity in relation to temperature. Ann. Entomol. Soc. Am 76: 310-313.

Byrne FJ, A.L. Devonshire. 1997. Kinetics of insensitive acetylcholinesterases in organophosphate-resistent tobacco whitefly, Bemisia tabaci (Gennadius) (Homoptera: Aleyrodidae). Pestic Biochem Physiol 58: 119-124.

Bayhan E, Ulusoy MR, Brown JK. 2006. Host range, distribution, and natural enemies of Bemisia tabaci B biotype (Hemiptera: Aleyrodidae) in several squash culitivars. J Pest Sci 83: 223229.

Bueno AF, M.J. Batistek, R.C.O.F Bueno, J.D. Franca-Neto, M.A.N. Nishikawa, A.L. Filho. 2011. Effects of integrated pest management, biological control and prophylactic use of insecticides on the management and sustainability of soybean. Crop. Prot. 30: 937-945.

Gamel Ol. 1974. Some aspect of the mating and oviposition behaviour of the cotton whitefly Bemisia tabaci (Genn.). Rev. Zool. Afr. 88 (4): 784-788.

Gulluoglu L, H. Arioglu, C. Kurt. 2010. Field evaluation of soybean cultivars for resistance to whitefly (Bemisia tabaci Genn.) infestations. Afr. J. Agric. Res. 5 (7): 555-560.

Horowitz AR, I. Ishaaya. 1996. Chemical control of Bemisia - management and application. In: Gerling D, Mayer RT, editor. Bemisia: Taxonomy, Biology, Damage, Control and Management. London, Great Britain. London (GB): Andover. 537-556 pp.

Hilje L, F.J. Morales. 2008. Whitefly bioecology and management in Latin America. In: Capinera J, editor. Encyclopedia of Entomology. Springer, New York.

Hoddle M. 2013. The biology and management of the silverleaf whitefly, Bemisia argentifolii Bellows and Perring (Homoptera: Aleyrodidae) on greenhouse grown ornamentals. www. biocontrol.ucr.edu/bemisia.html.

Marwoto. 2007. Dukungan pengendalian hama terpadu dalam program bangkit kedelai. Iptek Tan. Pang. 2 (1): 79-92.

Marwoto, A. Inayati. 2011. Kutu kebul: hama kedelai yang pengendaliannya kurang mendapat perhatian. Iptek Tanaman Pangan 6 (1): 87-98.

Norris RF, E.P. Caswell-Chen, M. Kogan. 2003. Concepts in Integrated Pest Management. Prentice Hall. Upper Saddle River, New Jersey.

Palumbo JC, A.R. Horowitz, N. Prabhaker. 2001. Insecticidal control and resistance management for Bemisia tabaci. Crop Prot 20: 739-765.

Rahim A, Hastuti. 2007. Ekonomi Pertanian. Penebar Swadaya. Jakarta

Soekartawi. 1995. Analisis Usaha Tani. UI Press. Jakarta. 